\title{
E-CITIZENS WEB PORTAL - CASE OF CROATIA
}

\author{
Martina Tomičić Furjan ${ }^{1}$, Nikolina Žajdela Hrustek ${ }^{2}$ \\ and Igor Pihir ${ }^{3}$
}

\begin{abstract}
Electronic government implies the use of information and communication technology (ICT) for improving the way public services are provided to all citizens. In order to create an interface, through which citizens can use these services, web portals are developed. The web portal that represents the interface for the use of services intended for citizens in the Republic of Croatia, as key users, was developed in the frame of e-citizens project, initiated by the Croatian government in year 2013. Since its inception, the portal has been continuously upgraded and complemented by new electronic services. The usage of the e-citizens portal however, despite the availability of services, does not follow the developing trends according to researches by the local Ministry of Administration and the Eurostat data. Citizens access the portal, but mostly to collect information and do not use its advanced additional functionalities. This paper analyses Croatian government web portal, its functionalities, attitudes toward it and its use by citizens. Finally, based on data analysis improvement of the accessibility/usage of Croatian government portal will be proposed.
\end{abstract}

\section{Introduction}

The word 'government' has several meanings, of which two are basic: a set of administrative organizations and the meaning of a particular activity [13]. To govern means to carry out joint activities in order to achieve a specific goal, through the decision-making process and implementation of these decisions.

In the initial period of creating the state, the state administration has included classic resumes such as defence, police, diplomacy, justice and finance, with the task of acting authoritatively, ignoring thereby the interests of citizens. Towards the end of the 19th century, the role of state administration was changing, encompassing activities whose primary purpose is to care for society, including education, social welfare, health, traffic, communal services, statistics, cadastre and other information services [9]. Towards the end of the eighties and early nineties of the last century, the New Public Management (NPM) is emerging, which places the citizen as a public service user in the centre of public administration. Osborne and Gaebler [12] published their work "Reinventing government" in 1992, which suppresses the control of public sector from being bureaucratic to society oriented.

With the growing development of information and communication technologies (ICT), the concept of electronic government emerged in the late 1990s and early 21 st century. Electronic Government (e-government) is the application of information technology to the governing process with the aim of improving services for all its users [2].

\footnotetext{
${ }^{1}$ Faculty of Organization and Informatics, Varaždin, University of Zagreb, Croatia

${ }^{2}$ Faculty of Organization and Informatics, Varaždin, University of Zagreb, Croatia

${ }^{3}$ Faculty of Organization and Informatics, Varaždin, University of Zagreb, Croatia
} 
The program of the Croatian government for the mandate between 2016 and 2020 [14] in one of its chapters defines modernization of the government through informatization of all public services as one of main goals. In Croatia, there are 91 services that are currently active and supported by ICT on some level of informatization [15,8]. Since these public services are results of processes, mainly performed for citizens as their consumers, on state, regional and local level, the processes themselves should be improved by use of ICT. The mentioned goal of the Croatian government is operationalized through the Strategy e-Croatia 2020 [10], which defines that e-services should be available through the e-citizen system, which is implemented through a web portal. Implementation of public e-government services should imply further use in more complex systems. One example of this use is state aid for schooling (grants, transport of students, subsidized meals etc.), that is implemented in the project e-Schools: Establishing a System for Developing Digitally Mature Schools [1], which is currently in progress in its pilot phase in Croatia.

\section{E-citizens web portal}

Web portal system called The e-Citizens system [8] was developed by Croatian government in year 2013, with the aim of modernization and simplification of government to citizens and citizens to government communication. Electronic services and their availability in one-point-of-contact public web portal should increase transparency and raise the quality of public service to citizens [8]. E-citizens web portal consist of three major parts that made one system for public and private use by citizens but represents one whole [8]:

1) the Central Government Portal which is the public part of the system

2) the Personal User Mailbox

3) the National Identification and Authentication System.

\subsection{Central Government Portal}

The central government portal represents the public part of the web portal for citizens and it's purpose is to present the structure, function and role of all state administration bodies in a single place, in a simple and modern way. The central government portal covers 12 fields of public services [15] (eg. health, employment, citizenship and personal documents...) and shares more than 485 information articles. Citizens can browse through information about available public services and be redirected to login to e-services available in the personal user mailbox, described in the next chapter.

\subsection{Personal User Mailbox}

The Personal User Mailbox is a private user system, protected by login credentials available to every citizen in Croatia with valid personal identification number - OIB and the appropriate credentials [17]. Citizen can access available services of their interest but also get personal messages in order to be informed about personal documents and citizens' rights for personal use like expiration of ID card, passport, driver's license or vehicle registration, polling station, rights from pension and health insurance, rights during unemployment all the way up to notification about vaccination of pets [16]. The Personal User Mailbox is available through secured web application, is also provided for smart phones Android, iPhone/iPad and Windows Phone. 


\subsection{National Identification and Authentication System}

National Identification and Authentication System - NIAS is single point of identification and authentication of citizens' identity. Through NIAS, citizen can access e-government services listed on the central government portal and/or use them in the personal user mailbox. NIAS is a solution for identifying and authenticating users at the national level, enabling multiple types of credentials of different levels of security to be included from level 2 (lowest) to 4 (highest). This feature allows citizens to login to the e-citizen system and their personal user mailbox with already owned credential issued at other governmental systems, agencies or public content providers verified with NIAS system [8], [10], [5]. List of currently active credentials could be found at https://nias.gov.hr/Authentication/Step2; this list includes personal citizens credentials, mtoken from financial institutions, AAI educational identity credentials, credentials from several major banks used for Internet banking and other certification providers like Croatian FINA. Altogether, 16 credentials are available for use of e-services in Croatia.

According to available data from 9th November 2017, the total number of unique users with credentials is 479.848 , which makes a population of all potential users that already own at least one credential supported within the NIAS system [6]. So far, access to the e-citizen system was granted to 359,979 citizens and they use it through 4,513,749 login sessions into the system [7].

\section{Research data and methodology}

For the purposes of further informatisation of public administration, as well as development of public e-services, The Ministry of Administration of Republic of Croatia has conducted a research on the citizens' satisfaction with electronic services and information offered by the public administration [11]. A measurement instrument (questionnaire) was developed in order to include citizens as interest parties into the creation of new public e-services and information available online. The purpose of the created measurement instrument (questionnaire) was to examine the following: which information and e-services are expected to be available on behalf of public administration, the citizens' perception connected to the quality of information and public e-services and, among others, identification of key problems and obstacles conquered by the users while using public e-services.

Measurement instrument (questionnaire) was divided into two main groups of questions. The first group consisted of questions connected to perception and usage of electronic services and information available on behalf of public administration, while the second group of questions was connected to examinees' demographic data. The group of questions connected to perception and usage of electronic services and information, consisted of 9 sub-questions used to examine the perception of examinees on the importance of access to public services and information via Internet; connected to the area of employment, judicial system, health and health services, consumers' rights, education, public data, space and environment, library catalogues, voting and citizens' participation in online public discussions and information connected to defenders and especially sensitive groups of citizens. This set of questions also consisted of questions connected to examining the citizens' satisfaction with provided information and e-services on behalf of public administration, problems and obstacles encountered during the use and possibilities of improving the e-services of public administration. For the purpose of a more complete analysis, a group of demographic questions was used in order to gather information on gender, age, level of education as well as level of informatical knowledge, profession, personal income, the availability of information and communication technologies and research participants' area and place of residence. The questions in 
the measurement instrument (questionnaire) were created in form of an enclosed type with answers suggested ("Yes", "No"; "Insignificant" to "Important"; "Absolutely yes" to "Absolutely no", and additionally suggested options of answers connected to limitations, ie. obstacles in the usage of eservices) and open-type questions. The questionnaire was approached voluntarily and anonymously. The questionnaire was accessible online on the websites of the Ministry of Administration and via the e-citizen system. The period of gathering information lasted from December 17, 2014 to March 1, 2015. During the aforementioned period, over 5,100 examinees completed the questionnaire, but only 3,268 fully completed questionnaires were taken into consideration due to completeness of information taken during analysis procedures. A report was made based on the data gathered, which is accessible to the public on the websites of the Ministry of Administration of Republic of Croatia, but apart from the report on the Portal of public data [11], the original data was also published in the machine-made readable .csv form, which enabled further processing for scientific-research or business purposes to all interested users. The gathered answers served, among others, for the creation of "Draught of Strategy e-Croatia 2020".

For the purpose of this research, data and process analysis was made, and the data was taken from the previously mentioned website [11] and was elaborated via descriptive statistical analysis. The most significant results are presented in the continuation in their graphic form and are additionally descriptively explained.

\section{Data analysis}

An analysis of research results based on gathered/acquired data is presented in the continuation of this paper.

\subsection{Demographic characteristics of respondents}

Out of the total number of examinees $(\mathrm{N}=3268), 36 \%(\mathrm{~N}=1167)$ were women and $64 \%(\mathrm{~N}=2101)$ were men. Representation of all age groups was noticed. The majority of participants $(33.8 \%$, $\mathrm{N}=1105$ ) belonged to the age group of 25-34 years of age, while the least number of participants $(0.3 \%, \mathrm{~N}=9)$ were younger than 18 and older than 75 . According to level of education, all suggested groups were represented as well, starting with $0.2 \%(\mathrm{~N}=6)$ with unfinished primary school and finishing with $10.5 \%(\mathrm{~N}=344)$ with postgraduate education, $52.3 \%(\mathrm{~N}=1708)$ of examinees were with undergraduate/graduate education. Connected to the level of computer literacy, the participants had to estimate which group they belonged to: "Beginner", "Average" or "Advanced" Internet users. 63.1\% ( $\mathrm{N}=2062)$ said their knowledge was "Advanced", 35.5\% ( $=1159)$ were "Average", and $1.4 \%(\mathrm{~N}=47)$ put themselves in the "Beginner" group. In relation to profession, the majority of participants $(19.2 \%, \mathrm{~N}=626)$ said they worked in Natural science-technical department, 15.2\% $(\mathrm{N}=496)$ worked in Social-humanistic area, followed by $11.8 \%(\mathrm{~N}=384)$ of "Office and counter clerks", and the least of $0.5 \%(\mathrm{~N}=17)$ were "Agricultural, hunting-breeding, forestry workers or fishermen". In relation to monthly income, $36.0 \%$ (1177) participants said they had average monthly income $(3500.00-6500.00 \mathrm{kn})$, while $33.6 \%(\mathrm{~N}=1097)$ received less than $3500.00 \mathrm{kn}$ monthly. Data on possibilities and mode of Internet access show the majority of participants (98.6\%, $\mathrm{N}=3223)$ have the possibility of Internet access, while most of them $(55.5 \%, \mathrm{~N}=1788)$ access the Internet via xDSL, and $1.4 \%(\mathrm{~N}=45)$ declared they do not want to have Internet access, due to financial or technical circumstances. According to place of residence ie. county, 37.2\% $(\mathrm{N}=1212)$ of participants lived in Zagreb, while only $0.7 \%(\mathrm{~N}=27)$ lived in Ličko-senjska county. According to place of residence and related to the number of examinees, the majority of participants 
(55.9\%, N=1828) lived in localities with over 35001 inhabitants, while the least number of participants $(4.9 \%, \mathrm{~N}=161)$ lived in localities with less than 500 inhabitants.

\subsection{Importance of access to public services by specific areas}

Data analysis established that over $96.0 \%$ of examinees said the online access to information and public services is "Considerably important" or "Important" when "the access to personal data on health services, health itself and making appointments for health services" is concerned. Over $91.0 \%$ of examinees are interested in "the access to judicial registers and services", while $87.0 \%$ of examinees show interest in "the access to information and advice on consumers' rights" and "online voting". Among all suggested areas of access to public information and services, the least number of examinees $(46.6 \%)$ show interest in information on health and services connected to "Croatian defenders' rights" and "services of inclusion of especially sensitive groups" (54.7\%). Considering the preferences of importance according to demographic characteristics, such as gender, three services/information present no difference in preferences to both genders. "The access to personal information on health services, health itself and making appointments for health services" and "the access to judicial registers and services" are "Considerably important" or "Important". According to age, "the access to personal information on health services, health itself and making appointments for health services" is "Considerably important" or "Important"; the difference is the younger age groups show more interest in "online voting", while older age groups are more interested in "the access to judicial registers and services" and "the access to information and advice on consumers' rights".

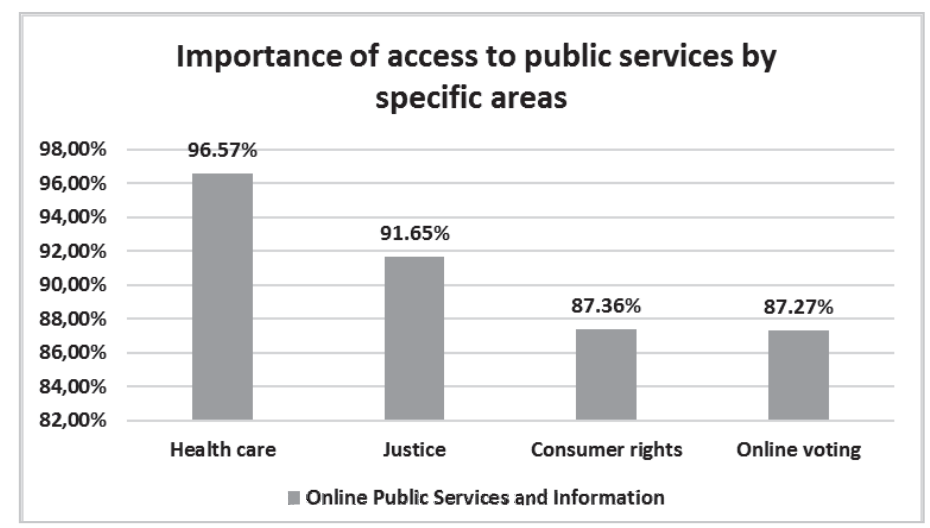

Figure 1: The importance of access to public service by specific areas

\subsection{Information requested on public administration's websites within the last 12 months}

Among the information the examinees searched for mostly on websites of public adminstration's bodies, one can isolate the information connected to "Personal documents" (e.g. passport, civic states, birth certificate etc.), over $84.0 \%(\mathrm{~N}=2754)$. Over $70.0 \%$ (2312) examinees searched for information on "Health and retirement insurance, social support, child's allowance". Since the unemployment rate in Croatia is high, $49.0 \%$ of examinees searched for information on "Employment", which is followed by 48.0\% ( $\mathrm{N}=1580)$ of searches on "Vehicles" (eg. driver's licence, registration) and $47.0 \%(\mathrm{~N}=1567)$ of searches on "Banking". A little over $12.0 \%$ of examinees searched for the information on "Public acquisition", and $19.0 \%$ of searches was 
directed to "Information on culture and tourism". According to gender, both groups of examinees were mostly interested in information on "Personal documents" (e.g. passport, civic states, birth certificate, etc.), while the second category with most searches was, with male population, "Health", then "Vehicles" (e.g. driver's licence, registration). With female population, the second category with most searches was "Health and retirement insurance, social support, child's allowance", followed by "Vehicles". According to age groups, all age groups are equally most interested in information on "Personal documents", "Health and retirement insurance, social support, child's allowance" and "Vehicles" (e.g. driver's licence, registration).

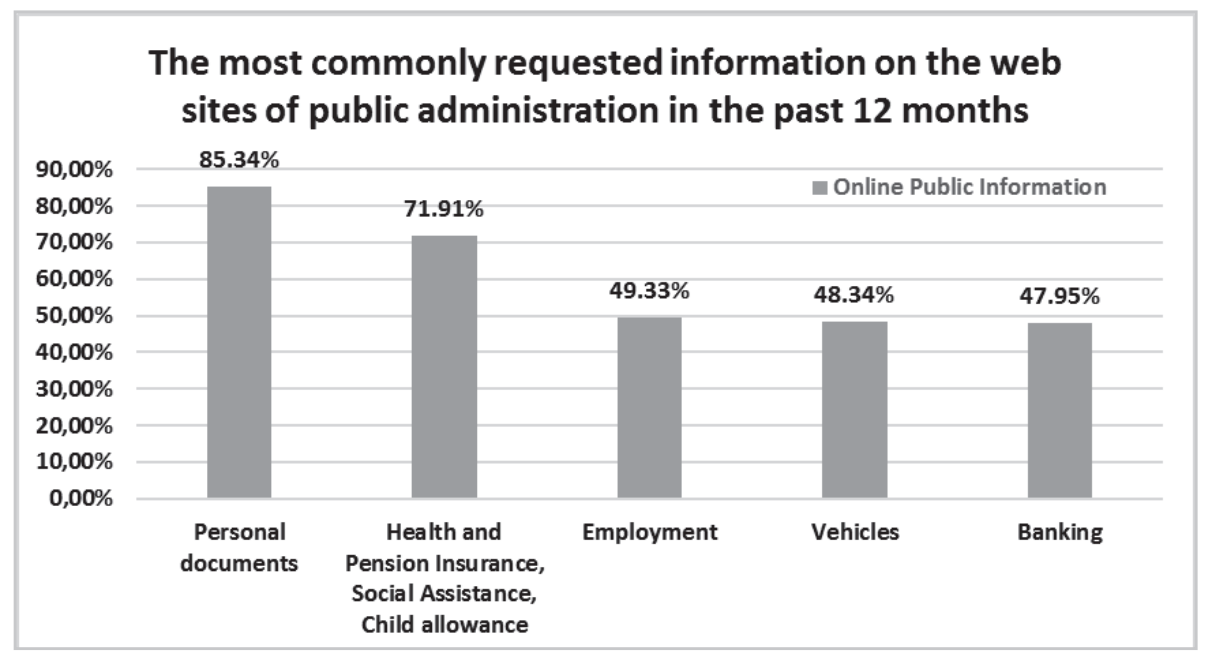

Figure 2: The most commonly requested information on the web sites of public administration in past 12 months

\subsection{Experience in interacting with public administration while working on a request via its websites or online services within the last 12 months}

Using websites or online services while dealing with wanted administrative requests was questioned in the manner that the examinees had to choose one out of eight claims. $36.8 \%(\mathrm{~N}=1204)$ out of the total number of examinees $(\mathrm{N}=3268)$ expressed a potitive attitude and said they were "satisfied with the way the body of authority solved their question". Among the presented flaws connected to the electronic business of public administration, over $21.0 \%(\mathrm{~N}=685)$ examinees said "dealing with the wanted administrative request is impossible via the Internet", $10.6 \%(\mathrm{~N}=346)$ said "the procedure of handing in and processing the requests is complicated and instructions are difficult to understand", and little less than $10.3 \%(\mathrm{~N}=335)$ declared "the processing of their administrative question took longer than expected". 7.9\% ( $\mathrm{N}=259)$ examinees said they "have not received neither the answer nor a response from the body of authority", 3.3\% ( $\mathrm{N}=107)$ said "the form was too difficult and instructions were missing or were not understandable", and 2.8\% ( $=92)$ came across "technical problems" while using the website or public administration's online service. Taken from the perspective of changes introduced by public administration and connected to websites and online services, $40.9 \%(\mathrm{~N}=1336)$ of examinees said they noticed the said changes and no less than $78.0 \%$ $(\mathrm{N}=1042)$ considered them "positive". 


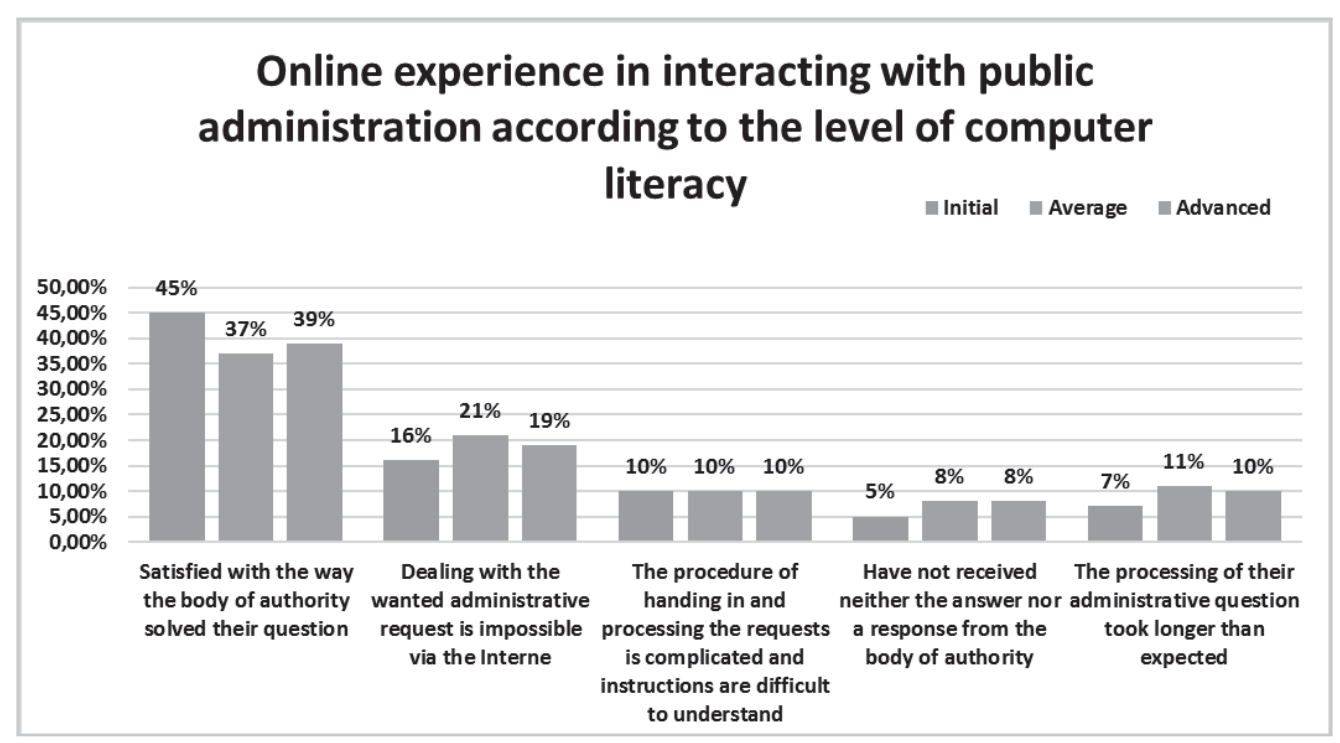

Figure 3: Online experience in interacting with public administration according to the level of computer literacy

\subsection{Examinees' interest in using online public bodies' services}

When asked about the interest in using online public bodies' services, the answers provided by examinees clearly show that the interest is very high. $98.8 \%$ or $(\mathrm{N}=3229$, with total $\mathrm{N}=3268)$ declared themselves with "Absolutely yes" or "Probably yes", while only $0.5 \%(\mathrm{~N}=15)$ said they "would not" use the said services, ie. $0.7 \%(\mathrm{~N}=24)$ said they "do not know" how to use them. The analysis according to age groups shows that the greatest interest in using online public bodies' services among the examinees is in groups 25-34 and 35-44 years of age.

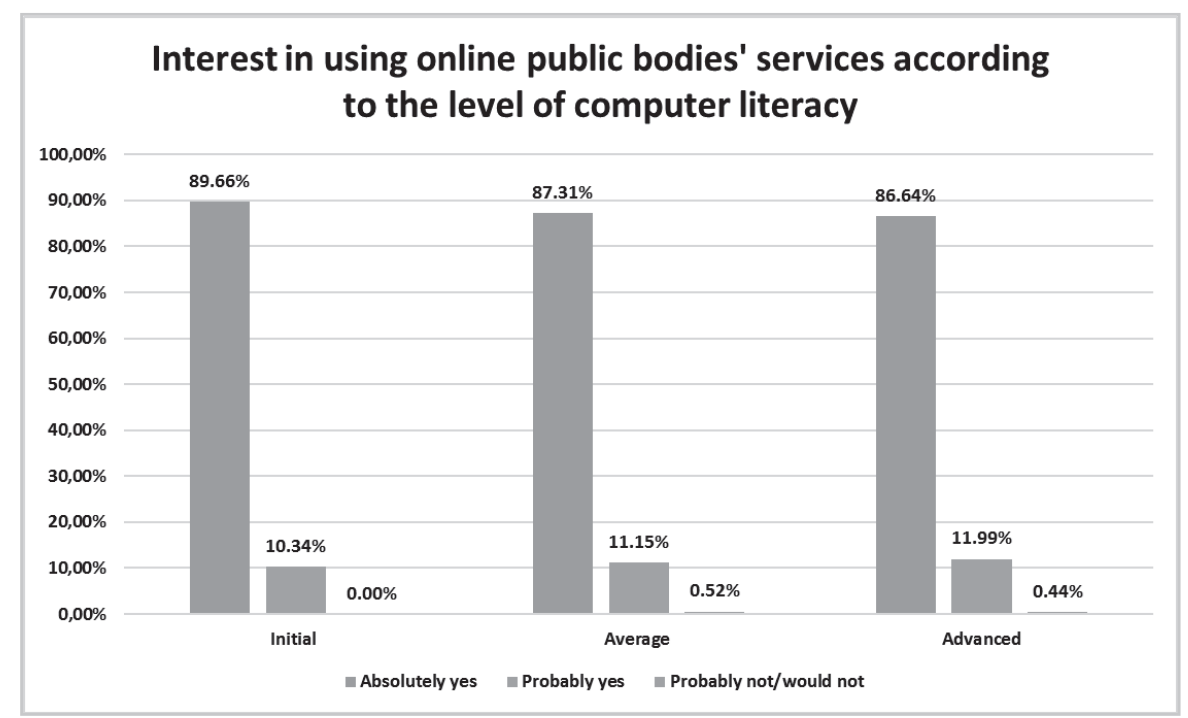

Figure 4: Interest in using online public bodies' services according to the level of computer literacy 


\subsection{Limitations in using online services}

The continuation of this paper will present the most important limitations the examinees consider to be key limitations while using online public administration services. "The small number of available services" was isolated as the most important limitation (24.9\%; $\mathrm{N}=2082)$, which is followed by limitation connected to dealing with further procedures after the completion of online forms due to the inability of using the e-signature. "In the end, I still have to go to the authorised office in order to personally sign or collect the wanted document" $(19.6 \%$; N=1634). 18.7\% $(\mathrm{N}=1565)$ of participants said there is "a lack of services the citizens are interested in", while a little over $10.2 \%(\mathrm{~N}=855)$ said there is "a lack of information on how to operate". As the fifth most important limitation $(10.0 \% ; \mathrm{N}=835)$, the citizens' mistrust and concerns connected to online services are mentioned, ie. "the insecurity whether requests will eventually be handled with properly". $2.4 \%(\mathrm{~N}=198)$ of examinees agreed with the claim that "the security is not on a required level", when the issue of privacy and personal data protection is mentioned. It is interesting to emphasise that only $7.0 \%$ of examinees said there are "no limitations for them" while using online public services, while only $1 \%(\mathrm{~N}=85)$ declared they have "bad experience" while using public online services.

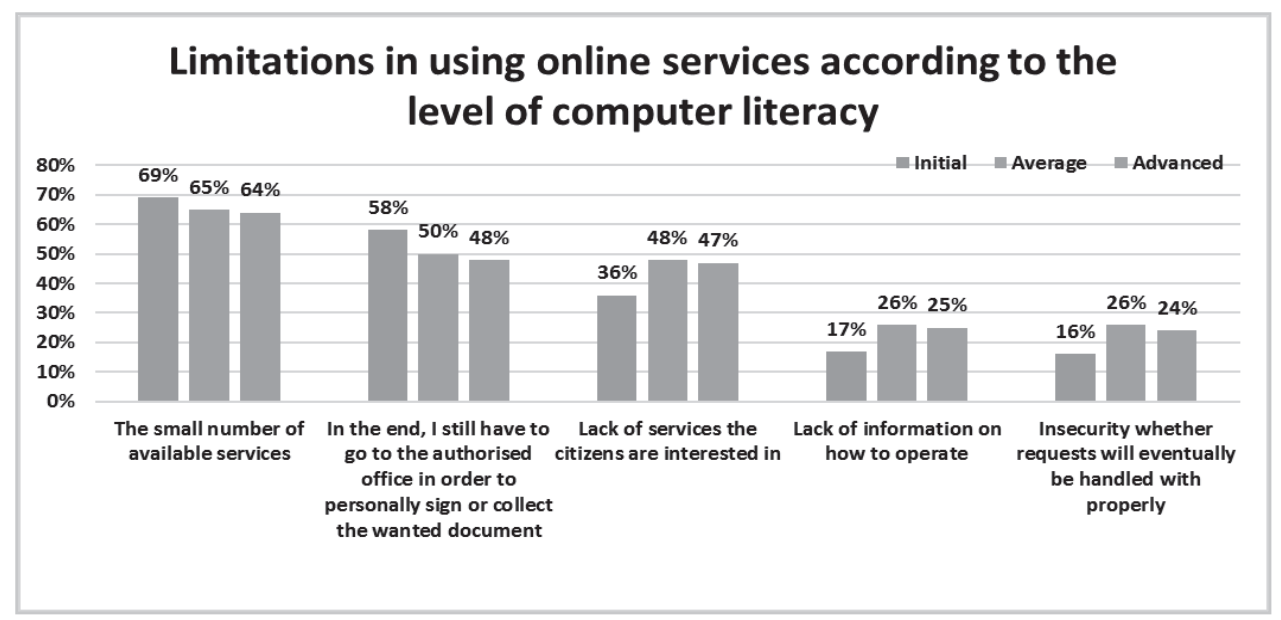

Figure 5: Limitations in using online services according to the level of computer literacy

\subsection{Data analysis - The most important services and information on the public sector which need to be accessible online}

In this part of the measurement instrument (questionnaire), the research participants had to make a decision on three most important areas, which should be provided online by the public administration. The majority of examinees, over $20.0 \%$, agreed this should be the information and services connected to "Finances and taxes", while the second most important area of their choice, for over $16.0 \%$ of examinees, was "Health". Over $10.0 \%$ of examinees are interested in services and information connected to "Legal state and security", over 9.0\% are interested in "Upbringing and education", and over $8.0 \%$ want to know more about "Employment". The least number of examinees, less than $0.7 \%$, declared themselves as having interest in information and services connected to "Culture", while less than $1.1 \%$ out of the total number of examinees want to know more about "Tourism". 


\section{Discussion and Recommendations for improvement}

European statistics show that citizens of Croatia interact with the state administration using egovernment services in 32\% of cases while the EU 28 average for 2017 is $49 \%$. Most advance EU member state is Denmark with $89 \%$ [4]. When viewed from the perspective that Croatia joined the European Union as a last member state in year 2013, these results should be considered as good in relation to other comparable EU countries (like Bulgaria, Romania, Poland etc). From the point of availability and level of informatisation of e-services, their quantity and quality, through the analysis in this paper, few limitations of current e-government system were identified, and as a conclusion of this paper, there are some recommendations that can be used for improvement of the identified limitations:

1) The small number of available services - from the citizen's perspective the number of online services is limited, and they need to choose what to do "online" and what "manually" in government offices. Our recommendation is to make more services electronic, in accordance with the goal mentioned in the introduction of this paper and defined in the Strategy e-Croatia 2020 [10].

2) Dealing with further procedures after the completion of online forms due to the inability of using the e-signature -some services can be started or initiated "online" but citizen still need to do "manual" steps in order to finish the service in government offices. This happens due to the lack of electronic identity and personal certificate and/or its corresponding security level for every citizen. Without appropriate credentials, some services are not electronically covered from-start-to-finish, and that prevents government bodies and agencies to create complete electronic services. Recommendation is to make services completely electronic (from request to the end of service) and that means to build necessary infrastructural, legal and practical environment for that. Multiple use of e-identity (personal certificate of citizens, commonly on every identity card in developed countries) in real life processes would be cost effective. Recommendation is also to do a systematic analysis of all services ("e-services" and "manual services") from process perspective, by using the Process life cycle described in Dumas et al [3] and systematically build the environment for complete e-government. Best practice and known solutions from other leading countries in the field of e-government should as well be used for implementation of this recommendation.

3) A lack of services the citizens are interested in - Recommendation is to give the opportunity to citizens to say what they consider important and then to use scientific research analysis and results as a baseline to decide what services are more important and more useful to citizens. Some areas of governmental services are already described and ranked by citizens' perspective of what is important to be available as an e-service in the analysis in this paper (see chapter 4.7.) and this can be further researched.

4) A lack of information on how to operate - from the citizens perspective, some e-service delivery ways are "to complicated", or just too "new", and they feel more secure and confident doing them "manually", rather than first learn how to do them online and then really try doing them online. Recommendation is to create: guidelines for every e-service, video instructions, build e-service applications as an expert system that helps users to define what they need and help them go through the whole e-service process step-by-step. So called "smart systems or virtual assistant systems" could be used to guide citizens through the whole e-service. Also, 
emphasis on the benefits of every e-service (time and cost savings), would give citizens more motivation to use them in the electronic way.

5) The insecurity whether requests will eventually be handled with properly - citizens feel unsafe in an online environment, they don't trust new technology or have insufficient computer skills to comformly use e-services instead of manual services. Recommendation is to work more in general on raising citizens' awareness of the role of public administration, on increasing public trust in the government and the public institutions and the processes that are being run and implemented there.

\section{References}

[1] CARNet, e-Schools: Establishing a System for Developing Digitally Mature Schools (pilot project) - Project description, Accessed $1^{\text {st }}$ December 2017 from www.e-skole.hr/en/eschools/project-description/ .

[2] CHEN, H., BRANDT, L., GREGG, V., TRAUNMUELLER, R., DAWES, S., HOVY, E., MACINTOSH, A. and LARSON, C. A., Digital Government, E-government Research, Case Studies, and Implementation. Springer, New York, USA 2008.

[3] DUMAS, M., LA ROSA, M., MENDLING, J. and REIJERS, H. A., Fundamentals of Business Process Management, Springer Verlag, Berlin 2013.

[4] Eurostat, Individuals using the internet for interaction with public authorities, Accessed 1st December 2017 from http://ec.europa.eu/eurostat/tgm/table.do?tab=table\&init=1\&language= en\&pcode $=$ tin $00012 \&$ plugin $=1$

[5] FINA, ePASS, FINA, 2017, Accessed 1st December 2017 from https://epass.gov.hr .

[6] gov.hr a, C_KorisniciSustavaEgradani - Ukupni broj jedinstvenih korisnika. Accessed 1st December 2017 from https://gov.hr/UserDocsImages//Data\%20za\%20datagov.hr/MURH eGradjaniStat//C_KorisniciSustavaEgradani.xml

[7] gov.hr b. D Koristenje usluga, Accessed 1st December 2017 from https://gov.hr/UserDocs Images//Data\%20za\%20datagov.hr/MURHeGradjaniStat//D_Koristenje_usluga.xml .

[8] Government of the Republic of Croatia, The e-Citizens system, 2017, Accessed $1^{\text {st }}$ December 2017 from https://vlada.gov.hr/the-e-citizens-system/15215 .

[9] KOPRIĆ, I., Javna uprava - nastavni materijali, ur. Koprić, I., Suvremena javna uprava, Zagreb 2006.

[10] Ministarstvo uprave a, Strategija e-Hrvatska 2020, Ministarstvo uprave RH, Hrvatska, 2017.

[11] Ministarstvo uprave b. Zadovoljstvo građana elektroničkim uslugama i informacijama u javnoj upravi podaci istraživanja. Ministarstvo uprave, 2015, Accessed 1st December 2017 from http://data.gov.hr/dataset/zadovoljstvo-gradjana-elektronickim-uslugama-i-informacijam a-u-javnoj-upravi 
[12] OSBORNE, D. and GAEBLER, T., Reinventing government, Addison-Wesley Publ. Co., USA 1992.

[13] PUSIĆ, E., Nauka o upravi, Školska knjiga, Zagreb 2002.

[14] Vlada RH a, Program Vlade Republike Hrvatske za mandat 2016-2020. Vlada RH, Hrvatska, 2016.

[15] Vlada RH b, Središnji državni portal - Moja uprava, Vlada RH, Hrvatska, 2017, Accessed $1^{\text {st }}$ February 2018 from www.gov.hr/moja-uprava/22

[16] Vlada RH c, O središnjem državnom portalu, Vlada RH, Hrvatska, 2017, Accessed $1^{\text {st }}$ December 2017 from www.vlada.gov.hr/sredisnji-drzavni-portal/203 .

[17] Vlada RH d, Osobni korisnički pretinac, Vlada RH, Hrvatska, 2014, Accessed $1^{\text {st }}$ December 2017 from https://pretinac.gov.hr/KorisnickiPretinac/eGradani.html 